\title{
Evaluation of Sperm DNA Fragmentation using TUNEL Assay in Different Animal Species
}

\section{Kurniawan Dwi Prihantoko ${ }^{1}$, Makruf Arif ${ }^{1}$, Asmarani Kusumawati ${ }^{2 *}$, Diah Tri Widayati ${ }^{3}$, Agung Budiyanto ${ }^{2}$}

${ }^{1}$ Postgraduate of Veterinary Science, Faculty of Veterinary Medicine, Universitas Gadjab Mada, Jl. Fauna No. 2, Karangmalang, Sleman, Yogyakarta 55281, Indonesia; ${ }^{2}$ Department of Reproduction and Obstetrics, Faculty of Veterinary Medicine, Universitas Gadjah Mada, Jl. Fauna No. 2, Karangmalang, Sleman, Yogyakarta 55281, Indonesia; ${ }^{3}$ Department of Animal Breeding and Reproduction, Faculty of Animal Science, Universitas Gadjah Mada, Jl. Fauna No. 2, Karangmalang, Sleman, Yogyakarta 55281, Indonesia.

\begin{abstract}
The studies of spermatozoa DNA fragmentation at the level of different animal species are very limited. This study examined the sperm DNA fragmentation in several animal species (bulls, chickens, and mice) by utilizing terminal deoxynucleotidyl transferase-mediated dUTP nick end labeling (TUNEL) assay. This study used a total of 24 different semen samples of Peranakan Ongole (PO bulls) or Ongole grade bull, chickens (KUB Chicken), and mice. Eight semen samples each were collected by three different methods. Semen samples of Peranakan Ongole (PO) bull were collected by artificial vagina method, semen samples of Kampung Unggul Balitnak (KUB) chicken were collected by abdominal massage method, and semen samples of mice were collected by epididymal collection method. Evaluation rate included the motility (\%), viability (\%) by eosin-nigrosine staining method, membrane integrity (\%) by hypo-osmotic swelling test (HOST) method and sperm DNA fragmentation (\%) by the TUNEL assay method. The results showed mice had the highest DNA fragmentation rates as compared to others species under study, while bull semen samples showed the lowest rates of DNA fragmentation. Significant differences in mice semen could be affected by the quality of chromatin. The TUNEL method might not effectively interpret the chicken semen samples better than the bulls and mice. However, sperm DNA fragmentation can be used to determine semen quality comprehensively based on the rates of DNA damage.
\end{abstract}

Keywords | DNA fragmentation, Semen quality, Semen evaluation, Sperm, TUNEL

Received | June 14, 2021; Accepted | September 19, 2021; Published | December 01, 2021

*Correspondence | Asmarani Kusumawati, Department of Reproduction and Obstetrics, Faculty of Veterinary Medicine, Universitas Gadjah Mada, J1. Fauna No. 2, Karangmalang, Sleman, Yogyakarta 55281, Indonesia; Email: uma_vet@ugm.ac.id

Citation | Prihantoko KD, Arif M, Kusumawati A, Widayati DT, Budiyanto A (2022). Evaluation of sperm DNA fragmentation using TUNEL assay in different animal species. Adv. Anim. Vet. Sci. 10(1): 14-19.

DOI | http://dx.doi.org/10.17582/journal.aavs/2022/10.1.14.19

ISSN (Online) | 2307-8316; ISSN (Print) | 2309-3331

Copyright (c) 2022 Prihantoko et al. This is an open access article distributed under the Creative Commons Attribution License, which permits unrestricted use, distribution, and reproduction in any medium, provided the original work is properly cited.

\section{INTRODUCTION}

$\mathrm{F}$ rozen semen is an essential technology for artificial insemination or livestock resource development (Gliozzia et al., 2011). One of the most crucial aspects of cryopreservation is the quality of the semen itself. The sperm quality is evaluated by microscope characteristics evaluation, such as motility and viability (Venkatesh et al., 2011). The motility rates and individual motion serve as the fertilization indicator capacity, though it is unable to accurately predict the fertilization ability (Prihantoko et al., 2020a). A deep structure and mechanism evaluation of sperm may lead to a better understanding to predict both the semen capacity and ability to fertilize and resist cryopreservation. In the conventional assessment of semen quality, DNA status is not assessed even though the DNA integrity is essential in preventing failures in the fertilization process and embryo development (Gliozzia 
et al., 2011). However, as in humans, it is impossible to accurately assess the sperm by conventional method in predicting the male reproductive succession to AI (MingWen and Lloyd, 2020). Normal embryonic development depends on the sperms which can carry intact DNA (Aitken et al., 2013; Barratt, 2010). In both human and animal semen, DNA damage is caused by multiple factors, such as a lapse in spermiogenesis, weak chromatin compaction, sperm apoptosis, oxidative stress, drug agents, radiations, infections, and others (Sakkas and Alvarez, 2010).

The sperm DNA damage is an essential parameter to evaluate the semen before animal-assisted reproductive technology (ART) such as in-vitro fertilization (IVF) and artificial insemination (AI) is used (Takeda et al., 2015). DNA damage may cause failure in pregnancy and obstruct the artificial insemination process (Singh and Agarwal, 2011). However, the specific mechanism of DNA damage affecting male fertility remains unclear (Zini et al., 2011). The single-strand or double-strand breaks, deletions, and additions, or base modifications are involved in DNA damage (Takeda et al., 2015). Strand break in sperm DNA may be caused by reactive oxygen species (ROS) (Irvine et al., 2000). According to Agarwal and Allamaneni (2005), the single-cell gel electrophoresis (Comet assay) and terminal deoxynucleotidyl transferase-mediated dUTP nick end labeling (TUNEL) are the common methods for DNA fragmentation. The disruption of the DNA strand primarily caused by ROS (Tremellen, 2008) may be detected using the TUNEL assay (Takeda et al., 2015). The previous studies concluded that TUNEL assay is the most effective method to detect sperm DNA damage (Sharma et al., 2010, 2013; Takeda et al., 2015). Other studies conducted with different methods had shown a negative correlation between fertility rates and genetic material quality (Frazer, 2004; Gliozzia et al., 2011; Mahmoud et al.,2015). In humans, infertility is affected by higher levels of DNA damage (Irvine et al., 2000). The infertile sperm is found to be more susceptible to DNA damage (Gliozzia et al., 2011). Besides, the high percentage of DNA damage showed significantly lower conception rates, as detected by the TUNEL assay (Henkel et al., 2004). Further, it was found in a study that the semen percentage of TUNELpositive can determine the infertile men in the fertile group (Sharma et al., 2010).

The studies of sperm DNA integrity that have been carried out in humans (Donnelly et al., 2001) differed from those of bovine and birds in which the issue is not commonly studied (Madeddu et al., 2009). The sperm DNA integrity is commonly been studied in human and mice samples. The present study examined the sperm DNA fragmentation in bovine, chicken, and mice by terminal deoxynucleotidyl transferase-mediated dUTP nick end labeling (TUNEL) assay and correlation between sperm DNA damage and conventional semen quality parameters.

\section{MATERIALS AND METHODS}

\section{SEMEn Collection AND EVAluation}

This study used a total of 24 different semen samples of Peranakan Ongole bulls (Ongole grade bull), chickens (KUB Chicken), and mice, eight ejaculated semen samples each were collected from those three different species. Semen samples of Peranakan Ongole (PO) bull were collected by artificial vagina method from eight different Indonesian Ongole grade bulls aged 4 to 6 years old in health conditions with normal reproductive organs. The bulls were treated in Balai Pengembangan Bibit, Pakan Ternak dan Diagnostik Kehewanan Yogyakarta (Yogyakarta Animal Breeding Center, Indonesia). KUB chicken semen samples were collected by abdominal massage method at the field laboratory, Faculty of Veterinary Medicine, Gadjah Mada University, Indonesia. mice semen samples were collected by epididymal collection method at the Laboratory of Obstetrics and Gynecology, Faculty of Veterinary Medicine, Gadjah Mada University, Indonesia. The spermatozoa evaluation parameters include motility (\%), viability (\%), membrane integrity (\%), and DNA sperm fragmentation (\%).

\section{MotiLiTy OF SPERMATOZOA}

Sperm motility evaluation was subjectively assessed under a microscope. A drop of semen well-mixed in four drops of saline solution was placed on an object glass and covered with a coverslip. Sperm motility was being evaluated under $40 \mathrm{x}$ magnification in five different fields of the object glass. Then the evaluation was assessed in percentages on a scale range of $0-100 \%$.

\section{VIABILITY OF SPERMATOZOA}

Sperm viability was assessed by the eosin-nigrosin staining method (Telnoni et al., 2017). The procedure started by mixing $10 \mu \mathrm{L}$ semen with $20 \mu \mathrm{L}$ eosin-nigrosin (1:2) on an object glass. Followed by smear preparation was later using another object glass and fixation with a bunsen burner. Semen viability was later evaluated using a microscope under 40 magnification. Sperm viability were calculated by comparing the number of live and dead spermatozoa from a total of 200 sperm cells. An intact membrane of live sperm would prevent its staining, but the dead sperm showed otherwise.

\section{MEMBRANE INTEGRITY OF SPERMATOZOA}

The sperm membrane integrity was assessed by hypoosmotic swelling test (HOST) according to Akcay et al. (2012) method with a slight modification. $10 \mu \mathrm{L}$ of semen diluted with $100 \mu \mathrm{L}$ of HOST solution (a mixture of 0.9 fructose, $0.49 \mathrm{~g}$ of citrate sodium, and distilled water to a 
final volume of $100 \mathrm{ml}$ ) and incubated for 30 minutes at $37^{\circ} \mathrm{C}$. The solution was then smeared on the object glass, dried, and fixed.The membrane integrity rates were assessed by comparing the number of intact membrane sperm and the damaged membrane spermatozoa. The circular tail spermatozoa represent an intact membrane, but a damaged membrane showed otherwise with a straight tail.

\section{SPERM DNA FRAGMENTATION}

Sperm DNA fragmentation was examined by using the terminal deoxynucleotidyl transferase dUTP nick end labeling (TUNEL) assay or in-situ Cell Death Detection Kit, TMR Red version $12^{\text {th }}$ (Sigma-Aldrich, USA). The samples of semen were smeared to an object glass, dried, and fixated for an hour at $15-25^{\circ} \mathrm{C}$ followed by rinsed with phosphate buffer saline (PBS). The stained samples were added $0.1 \%$ Triton $\mathrm{X}-100$ in sodium citrate $0.1 \%$ for two minutes at $2-8^{\circ} \mathrm{C}$ and rinsed with PBS twice. The negative control was made by adding $50 \mu \mathrm{L}$ label solution and the positive control was made by incubating the samples with DNAse recombinant to induct DNA separation. The stained samples and controls were dried and mixed with the TUNEL assay reaction available in the kit at $37^{\circ} \mathrm{C}$ for 60 minutes and rinsed with PBS three times. The results were examined using a laser-scanning confocal microscope at a wavelength of $517 \mathrm{~nm}$. Spermatozoa in a bright green fluorescence showed damaged (fragmented) DNA, while spermatozoa in a dull green fluorescence showed normal DNA.

\section{Statistical ANALYsis}

Analytical descriptive and coefficient corelative were performed by SPSS version 24.0 (SPSS Inc., Chicago, IL, USA) as the analysis tool. Duncan's multiple range test was used for treatment comparisons.

\section{RESULTS AND DISCUSSIONS}

TUNEL assay is the most used method to evaluate DNA fragmentation. The TUNEL assay kits, relatively welldeveloped and cost-effective, are mass-produced. Also, it is simple to test TUNEL-positive spermatozoa through fluorescence microscope or flow cytometry (Sharma et al., 2013). We analyzed the semen samples through a microscope to further evaluate relations between DNA damage to the conventional semen quality parameters. Results of this study (Table 1, Figure 1) showed that motility rates in KUB chickens were the highest among others, and there was a significant difference in the semen motility rates of Peranakan Ongole breed bulls and KUB chicken samples compared to the mice samples $(\mathrm{P}<0.05)$. The sperm motility values from three different species were $81.13 \pm 1.64 \%$ for the PO bull samples, $83.88 \pm 1.25 \%$ for the KUB chicken samples, and $66.13 \pm 1.64 \%$ for the mice samples (Table 1). The sperm viability range between 63.75 $\pm 1.39 \%$ to $85.86 \pm 1.96 \%$ (Table 1$)$. The sperm viability values from three different species were $83.38 \pm 1.69 \%$ for the PO bull samples, $85.86 \pm 1.96 \%$ for the KUB chicken samples, and $63.75 \pm 1.39 \%$ for the mice samples (Table 1 ). The percentage of viability in KUB rooster and PO bulls showed relatively similar values, and there is no significant difference $(\mathrm{P}>0.05)$. The viability rates of Peranakan Ongole breed bulls and KUB chickens were relatively higher than the mice, and there was a significant difference $(\mathrm{P}<0.05)$. The sperm membrane integrity values from three different species were $70.86 \pm 1.13 \%$ for the PO bull samples, $87.25 \pm 1.49 \%$ for the KUB chicken samples, and $59.00 \pm$ $1.07 \%$ for the mice samples (Table 1). Percentage values of membrane integrity KUB Chicken and Peranakan Ongole breed bulls were higher than the mice (Table 1, Figure 1), and there was a significant difference between the KUB chickens and Peranakan Ongole breed bulls compared to the mice samples $(\mathrm{P}<0.05)$.

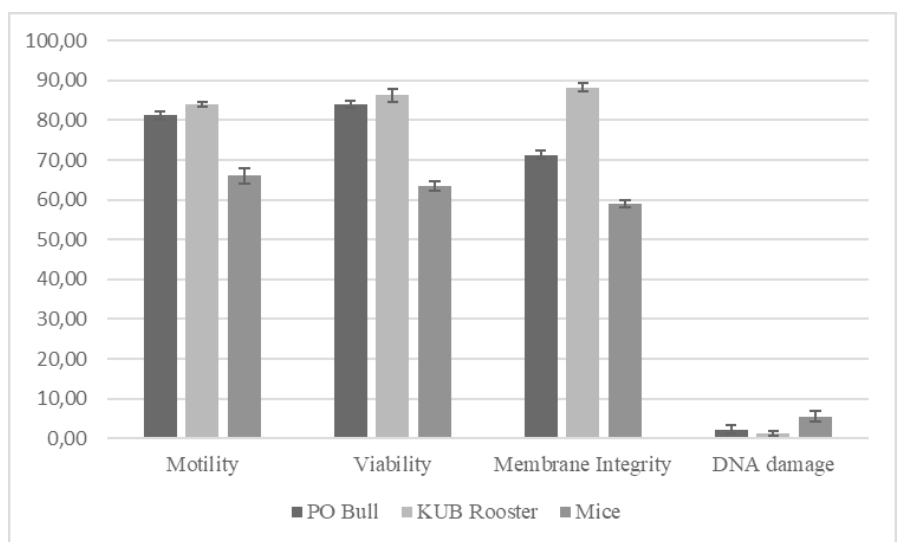

Figure 1: The total average of semen quality parameters from Peranakan Ongole breed bulls, KUB chickens, and mice. Error bar indicates standard deviation.

In three different samples (PO bull, KUB rooster, and mice), individual differences in DNA fragmentation results were found, we investigated the variance of the sperm DNA damage. These were the first study findings that showed different results in three different semen samples. The table showed the DNA fragmentation range values between 1.50 $\pm 0.53 \%$ to $5.50 \pm 1.51 \%$. The sperm DNA fragmentation values from three different species were $2.00 \pm 0.93 \%$ for the PO bull samples, $1.50 \pm 0.53 \%$ for the KUB chicken samples, and $5.50 \pm 1.51 \%$ for the mice samples (Table 1). The mice sperm DNA fragmentation had the highest values, and there was a significant difference between the mice to others $(\mathrm{P}<0.05)$. The analysis found that the percentage of fresh semen motility, viability, and membrane integrity had positive correlations with one another. On the contrary, the DNA damage showed negative correlations with others (Table 2).

Overall, KUB chickens had the lowest rates of sperm DNA 
damage. However, the DNA damage has probably stayed inherent to each semen. The sperm DNA damage rate in mice was the highest at a range between 5-8\% among the Peranakan Ongole breed bulls and KUB chickens ranging from 1-3\%. Numerous observations might affect the sample findings. This study also found that the TUNEL assay was not qualified to assess the semen of KUB chickens because the results from the fluorescent microscope were not as clear as the other samples (Figure 2). Other evaluation methods such as comet assay may the better methods to evaluate the sperm DNA fragmentation from chicken samples, as previously researched by Gliozzia et al. (2011). The mice semen samples showed the clearest fluorescent microscope results among others (Figure 2), though the main factor remains unknown. Which findings proved that different species samples and semen collecting methods might affect sperm DNA damage. Besides, the sperm DNA damage was not correlated with the semen quality parameters as sperm motility, viability, and membrane integrity. This finding is also in line with Takeda et al. (2015) which states that the results from the sperm TUNEL index were not correlated to conventional semen quality parameters. In several studies including this research, the fresh semen was evaluated without washing procedures. Although this method caused dead spermatozoa to be included in the analysis, such a procedure will not separate the spermatozoa with higher motility, and more valid results can be obtained. Fresh semen that is evaluated with washing procedures or centrifugation may reveal different results.

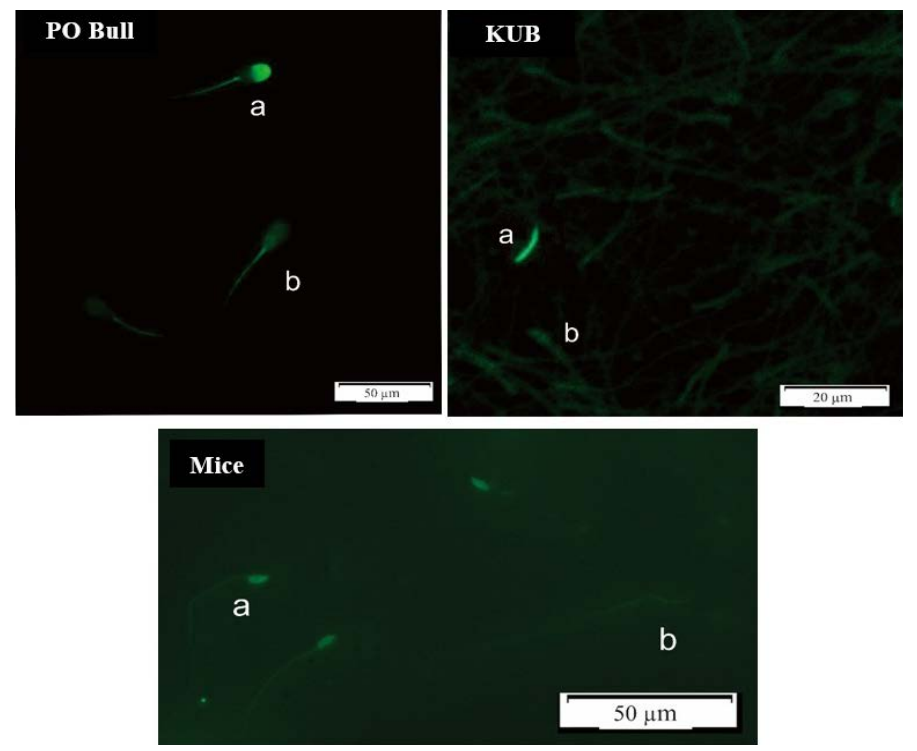

Figure 2: DNA Fragmentation results using the TUNEL assay method, spermatozoa in a bright green fluorescence showed damaged (fragmented) DNA (a), while spermatozoa in a dull green fluorescence showed normal DNA (b).

The DNA sperm cell is more susceptible to injury because of highly compact and stable chromatin compared to somatic cells with lower dense chromatin characteristics (Gliozzia et al., 2011). Chromatin condensation is an essential factor in the maturation process. It depends on the exchange between histones and protamines. The sperm ratio of histones and protamines depends on the variety and characteristics of species (Balhorn, 1982). This study found that KUB chicken had the lowest rates of sperm DNA damage. Some species lacked cysteine residues which cause high rates of DNA damage (Chiva et al., 1987). Though the used procedures were different, DNA damage did not correlate to other semen quality parameters (Table 2). Regardless of the sperm with lower motility and viability rate, it might have had high rates of DNA integrity. Previous studies in humans observed there was a connection between the comet assay, DNA strand breaks detection, and SCSA with the sperm chromatin resistance test to acid denaturation (Schlegel and Paduch, 2005; Aravindan et al., 1997). According to sperm cell studies, an increased denaturation sensitivity of sperm cells may lead to substantial DNA chain damage. It has partially been responsible for the denaturation susceptibility development of DNA sperm (Sailer et al., 1995).

A study found that infertile bulls had sperm DNA damage rates up to $25 \%$, contrary to the fertile bulls with less than $15 \%$ of sperm DNA damage (Anzar et al., 2002). It might presume that sperm DNA damage $<20 \%$ will not influence artificial insemination. Another study proved the TUNEL assay was an efficient technique to determine the consistency of young Norwegian red bulls' semen which concerns the pregnancy rate as a result of AI (Waterhouse et al., 2006). The present study result overview was in line with the human spermatozoa results (Zribi et al., 2010; Thomson et al., 2009). In humans, oxidative stress is more likely affecting sperm DNA fragmentation compared to others as caspase and apoptotic sequelae activation (Martin et al., 2004). Oxidative stress may affect every single part of sperm cells as lipids, proteins, nucleic acids, and sugars. Long-term lipid peroxidation can degrade the matrix structure of lipids. It causes the cell membranes to become unstable, disrupts the membrane function, and reduced membrane fluidity (Prihantoko et al., 2020b). The spermatozoa of bulls, with less than $4 \%$ of DNA damage, tend to have $10 \%$ higher performance of AI results as compared to the average rates (Takeda et al., 2015). In this study, evaluation of the three species sperm samples showed less than $10 \%$ of DNA damage. It is concluded that there are no correlations between sperm DNA damage, motility, and membrane integrity (\%). Similar findings have been published previously (Trisini et al., 2004). As for comparisons, other relevant studies did not report similar correlations or discordant results (Morris et al., 2002). Moreover, other methods may cause oxidative stress that leads to sperm DNA damage and affect semen quality. Another factor remains unknown, but it still can cause effects while the conventional semen parameters may not always associate with the DNA status. 
Table 1: Total average of fresh semen quality parameters and DNA damage from Peranakan Ongole breed bulls, KUB chickens, and mice.

\begin{tabular}{lllll} 
Samples & Motility (\%) & Viability (\%) & Membrane integrity (\%) & DNA damage (\%) \\
PO bull & $81.13 \pm 1.64^{\mathrm{a}}$ & $83.38 \pm 1.69^{\mathrm{a}}$ & $70.86 \pm 1.13^{\mathrm{b}}$ & $2.00 \pm 0.93^{\mathrm{ab}}$ \\
\hline KUB chicken & $83.88 \pm 1.25^{\mathrm{a}}$ & $85.86 \pm 1.9^{\mathrm{a}}$ & $87.25 \pm 1.49^{\mathrm{a}}$ & $1.50 \pm 0.53^{\mathrm{a}}$ \\
Mice & $66.13 \pm 1.64^{\mathrm{c}}$ & $63.75 \pm 1.39^{\mathrm{c}}$ & $59.00 \pm 1.07^{\mathrm{c}}$ & $5.50 \pm 1.5^{1 \mathrm{c}}$
\end{tabular}

a,b,c Different lowercase superscripts in the same row show the significant difference $(\mathrm{P}<0.05)$.

Table 2: The correlation rates among different parameters and DNA damage from Peranakan Ongole breed bulls, KUB chickens, and mice.

\begin{tabular}{llll} 
Parameters & \multicolumn{3}{c}{ Correlation coefficients } \\
Motility and Viability & PO bull & KUB chicken & Mice \\
Motility and Membrane integrity & $0.910^{* *}$ & $0.870^{* *}$ & $0.767^{*}$ \\
Motility and DNA damage & $0.705^{*}$ & $0.712^{*}$ & $0.814^{*}$ \\
Viability and Membrane integrity & -0.188 & 0.107 & 0.201 \\
Viability and DNA damage & $0.781^{*}$ & $0.747^{*}$ & $0.770^{*}$ \\
Membrane integrity and DNA damage & -0.183 & 0.341 & -0.204 \\
\hline
\end{tabular}

"= Significant at $\mathrm{P}<0.05 ; "=$ Significant at $\mathrm{P}<0.01$

\section{CONCLUSIONS AND RECOMMENDATIONS}

The TUNEL assay is reliable to assess DNA fragmentation in bulls and mice spermatozoa but not for the chickens. The sperm DNA fragmentation in mice showed the highest rates than the bulls samples. DNA damage or sperm DNA fragmentation assessment is an advanced parameter to determine sperm quality.

\section{ACKNOWLEDGMENTS}

This study is supported by Gadjah Mada University and the Ministry of Research, Technology and Higher Education, the Republic of Indonesia.

\section{NOVELTY STATEMENT}

Application of the TUNEL assay method on semen samples from Peranakan ongole bulls and KUB chicken has never been done before. The first comparison between three different animal samples (bull, chicken, and mice) for sperm DNA fragmentation.

\section{AUTHOR CONTRIBUTION}

All authors participate from the beginning of this study until the publications are released.

\section{CONFLICT OF INTEREST}

The authors have declared no conflict of interest.

\section{REFERENCES}

-Agarwal A, Allamaneni SS (2005). Sperm DNA damage assessment: A test whose time has come. Fertil. Steril., 84: 850-853. https://doi.org/10.1016/j.fertnstert.2005.03.080

- Aitken RJ, Bronson R, Smith TB, De Iuliis GN (2013). The source and significance of DNA damage in human spermatozoa, a commentary on diagnostic strategies and straw man fallacies. Mol. Hum. Reprod., 19: 475-485. https://doi.org/10.1093/molehr/gat025

-Akcay E, Kulaksiz R, Daşkin A, Çebi Ç, Tekin K (2012). The effect of different dilution rates on post-thaw quality of ram semen frozen in two different egg yolk free extenders. Slovenian Vet. Res., 49: 97-102.

- Anzar M, He L, Buhr MM, Kroetsch TG, Pauls KP (2002). Sperm apoptosis in fresh and cryopreserved bull semen detected by flow cytometry and its relationship with fertility. Biol. Reprod., 66: 354-360. https://doi.org/10.1095/ biolreprod66.2.354

-Aravindan GR, Bjordahl J, Jost LK, Evenson DP (1997). Susceptibility of human sperm to in situ DNA denaturation is strongly correlated with DNA strand breaks identified by single-cell electrophoresis. Exp. Cell Res., 236: 231-237. https://doi.org/10.1006/excr.1997.3719

- Balhorn R (1982). A model for the structure of chromatin in mammalian sperm. J. Cell Biol., 93: 298-305. https:/doi. org/10.1083/jcb.93.2.298

-Barratt CL (2010). Sperm DNA: Organization, protection and vulnerability: from basic science to clinical applications-a position report. Hum. Reprod., 25: 824-838. https://doi. org/10.1093/humrep/dep465

- Chiva M, Kasinski HF, Subirana JA (1987). Characterization of protamines from four avian species. FEBS Lett., 215: 237-240. https://doi.org/10.1016/0014-5793(87)80153-9

-Donnelly ET, Steele EK, McLure N, Lewis SEM (2001). Assessment of DNA integrity and morphology of ejaculated spermatozoa from fertile and infertile men before and after 
cryopreservation. Hum. Reprod., 16: 1191-1199. https:// doi.org/10.1093/humrep/16.6.1191

- Fraser L (2004). Structural damage to nuclear DNA in mammalian spermatozoa: its evaluation techniques and relationship with male infertility. Pol. J. Vet. Sci., 7: 311-321.

- Gliozzia TM, Zanibonib L, Cerolini S (2011). DNA fragmentation in chicken spermatozoa during cryopreservation. Theriogenology, 75: 1613-1622. https:// doi.org/10.1016/j.theriogenology.2011.01.001

-Henkel R, Hajimohammad M, StalfT, Hoogendijk C, Mehnert C, Menkveld R, Gips H, Schill WB, Kruger TF (2004). Influence of deoxyribonucleic acid damage on fertilization and pregnancy. Fertil. Steril., 81: 965-972. https://doi. org/10.1016/j.fertnstert.2003.09.044

-Irvine DS, Twigg JP, Gordon EL, Fulton N, Milne PA, Aitken RJ (2000). DNA integrity in human spermatozoa: Relationships with semen quality. J. Androl., 21: 33-44.

- Madeddu M, Berlinguer F, Ledda M, Leoni GG, Satta V, Succu S, Rotta A, Pasciu V, Zinellu A, Muzzeddu M, Carru C, Naitana S (2009). Ejaculate collection efficiency and postthaw semen quality in wild-caught Griffon vultures from the Sardinian population. Reprod. Biol. Endocrinol., 7: 18 -28. https://doi.org/10.1186/1477-7827-7-18

- Mahmoud KGM, El-Sokary AAE, Abdel-Ghaffar AE, Abou El-Roos MEA, Ahmed YF (2015). Analysis of chromatin integrity and DNA damage of buffalo spermatozoa. Iran J. Vet. Res., 16(2): 161-166.

- Martin G, Sabido O, Durand P,Levy R (2004). Cryopreservation induces an apoptosis-like mechanism in bull sperm. Biol. Reprod., 71: 28-37. https://doi.org/10.1095/ biolreprod.103.024281

-Ming-Wen L, Kent-Lloyd KC (2020). DNA fragmentation index (DFI) as a measure of sperm quality and fertility in mice. Nature, 10: 3833. https://doi.org/10.1038/s41598020-60876-9

- Morris ID, Ilotts S, Dixon L, Brison DR (2002). The spectrum of DNA damage in human sperm assessed by single cell gel electrophoresis (Comet assay) and its relationship to fertilization and embryo development. Hum. Reprod., 17: 990-998. https://doi.org/10.1093/humrep/17.4.990

- Prihantoko KD, Yuliastuti F, Haniarti H, Kusumawati A, Widayati DT, Budiyanto A (2020a). The acrosome integrity examination of post-thawed spermatozoa of several ongole grade bull in Indonesia using giemsa staining method. IOP Conf. Ser. Earth Environ. Sci., 478: 012042. https://doi. org/10.1088/1755-1315/478/1/012042

- Prihantoko KD, Yuliastuti F, Haniarti H, Kusumawati A, Widayati DT, Budiyanto A (2020b). The effect of genistein on the plasma membrane integrity of frozen ongole grade bull semen based on skim milk soy lecithin extender. IOP Conf. Ser. Earth Environ. Sci., 465: 012054. https://doi. org/10.1088/1755-1315/465/1/012054

- Sailer BL, Jost LK, Evenson DP (1995). Mammalian sperm DNA susceptibility to in situ denaturation associated with the presence of DNA strand breaks as measured by the terminal deoxynucleotidyl transferase assay. J. Androl., 16: 80-87.

-Sakkas D, Alvarez JG (2010). Sperm DNA fragmentation: mechanisms of origin, impact on reproductive outcome, and analysis. Fertil. Steril., 93: 1027-1036. https://doi. org/10.1016/j.fertnstert.2009.10.046

- Schlegel PN, Paduch DA (2005). Yet another test of sperm chromatin structure. Fertil. Steril., 84: 854-859. https://doi. org/10.1016/j.fertnstert.2005.04.050

- Sharma R, Masaki J, Agarwal A (2013). Sperm DNA fragmentation analysis using the TUNEL assay. Methods Mol. Biol., 927: 121-136. https://doi.org/10.1007/978-162703-038-0_12

- Sharma RK, Sabanegh E, Mahfouz R, Gupta S, Thiyagarajan A, Agarwal A (2010). TUNEL as a test for sperm DNA damage in the evaluation of male infertility. Urology, 76: 1380-1386. https://doi.org/10.1016/j.urology.2010.04.036

- Singh A, Agarwal A (2011). The role of sperm chromatin integrity and DNA damage on male infertility. Open Reprod. Sci. J., 3: 65-71. https://doi.org/10.2174/1874255601103010065

-Takeda K, Kyoko U, Masashi K, Takahiro T, Masahiro K, Shinya W (2015). Evaluation of sperm DNA damage in bulls by TUNEL assay as a parameter of semen quality. J. Reprod. Dev., 61(3): 185-190. https://doi.org/10.1262/jrd.2014-140

-Telnoni SP, Arifiantini RI, Yusuf TL, Darwati S (2017). Kedu semen cryopreservation in Beltsville poultry semen extender and lactated ringer's-egg yolk extender using dimethylsulfoxide. Asian J. Poult. Sci., 11: 14-19. https:// doi.org/10.3923/ajpsaj.2017.14.19

- Thomson LK, Fleming SD, Aitken RJ, De Iuliis GN, Zieschang JA, Clark AM (2009). Cryopreservation-induced human sperm DNA damage is predominantly mediated by oxidative stress rather than apoptosis. Hum Reprod., 24: 2061-2070. https://doi.org/10.1093/humrep/dep214

-Tremellen K (2008). Oxidative stress and male infertility a clinical perspective. Hum. Reprod. Update, 14: 243-258. https://doi.org/10.1093/humupd/dmn004

-Trisini AT, Singh NP, Duty SM, Hauser R (2004). Relationship between human semen parameters and deoxyribonucleic acid damage assessed by the neutral comet assay. Fertil. Steril., 82: 1623-1632. https://doi.org/10.1016/j. fertnstert.2004.05.087

-Venkatesh S, Shamsi MB, Deka D, Saxena V, Kumar R, Dada $R$ (2011). Clinical implications of oxidative stress and sperm DNA damage in normozoospermic infertile men. Indian J. Med. Res., 134: 396-398.

-Waterhouse KE, Haugan T, Kommisrud E, Tverdal A, Flatberg G, Farstad W, Evenson DP, De Angelis P M (2006). Sperm DNA damage is related to field fertility of semen from young Norwegian Red bulls. Reprod. Fertil. Dev., 18: 781788. https://doi.org/10.1071/RD06029

- Zini A, Jamal W, Cowan L, Al-Hathal N (2011). Is sperm DNA damage associated with IVF embryo quality? A systematic review. J. Assist. Reprod. Genet., 28: 391-397. https://doi. org/10.1007/s10815-011-9544-6

-Zribi N, Feki Chakroun N, El Euch H, Gargouri J, Bahloul A, Ammar Keskes L (2010). Effects of cryopreservation on human sperm deoxyribonucleic acid integrity. Fertil. Steril., 93: 159-166. https://doi.org/10.1016/j. fertnstert.2008.09.038 